\title{
Enhanced surveillance of shellfish mortality to improve early detection and investigation of outbreaks of exotic or emerging infectious diseases: An example of a mass mortality outbreak of mussels, France 2014
}

\author{
Lupo Coralie ${ }^{1,{ }^{*}}$, Prou Jean ${ }^{2}$ \\ ${ }^{1}$ Ifremer, Laboratoire de Génétique et Pathologie des Mollusques Marins, Avenue de Mus de Loup, F- \\ 17390 La Tremblade, France \\ ${ }^{2}$ Ifremer, Unité Santé, Génétique et Microbiologie des Mollusques Marins, Avenue de Mus de Loup, F- \\ 17390 La Tremblade, France \\ * Corresponding author : Coralie Lupo, email address : clupo@ifremer.fr
}

\begin{abstract}
:
This paper explores the relevance and feasibility of enhanced surveillance of mussel-related mortality based on regular telephone interviews of a key informant in a farming community. Based on qualitative analyses of data collected through semi-structured interviews, this method of participatory disease surveillance enabled the retrieval of high quality data during an outbreak of mussel mortality which occurred in Pertuis Charentais, France, in 2014.

The findings illustrated that such an enhanced surveillance approach compared with the institutional shellfish health surveillance system could improve the early detection of outbreaks of mussel mortality by one week. This approach enabled a detailed description of the outbreak, showing higher incidence proportion in the Northern water bodies. It also captured relevant data for hypothesis generation for further outbreak investigations, integrating a global view of the health and disturbance of the coastal marine ecosystem. However, to be effective and sustainable, this flexible approach requires a preexisting knowledge of the structure of the information network of the farmers' community. Such a community-based enhanced surveillance could increase the reactivity of the entire system to enable the earliest possible and most appropriate interventions to protect shellfish populations against exotic or emerging infectious diseases. This would also help to improve the vigilance of mussel farmers and foster their commitment, which is an essential element for sustainable shellfish health surveillance.
\end{abstract}




\section{Highlights}

- The relevance and feasibility of enhanced passive surveillance of mussel mortality were assessed. This flexible method was based on regular telephone interviews of a key informant from a farming community. This method improved the early detection and description of outbreaks of mussel mortality. This method was valuable for generating hypotheses for the future investigation of outbreaks. This method requires out-reach to the community-based information network of the mussel farmers.

Keywords : Early warning, Perception, Enhanced clinical surveillance, Shellfish diseases, Participative disease surveillance, Qualitative methods 


\section{Introduction}

In Europe, management of the health of marine mollusc shellfish primarily aims to prevent disease occurrence rather than controlling the disease once it has occurred (European Union, 2006). Early detection is thus crucial to mitigate the spread of an exotic or emerging pathogen. Surveillance of shellfish diseases is based on two complementary approaches. The first one is specific and targets regulated pathogens at the international (OIE, 2015) or European (European Union, 2006) levels. The second one is nonspecific and targets any abnormal mortality of shellfish (European Union, 2006). The rationale behind this general approach is that any mortality outbreak constitutes suspicion of the presence of an infectious disease, as diseased shellfish seldom show clinical signs (Lupo et al., 2012).

In France, the current surveillance system is mainly based on the observation of any increased shellfish mortality by shellfish farmers (Lupo et al., 2012) and its immediate notification to the local competent authority, which is the Departmental Direction for Territories and Sea (DDTM) (French Ministry of Agriculture, 2008). The DDTM then mobilizes the national mollusc disease surveillance network (Repamo) for an investigation that consists of anamnesis and laboratory diagnosis based on animal samples (Dufour and Hendrickx, 2009). The national reference laboratory (NRL) for mollusc diseases and its dedicated network of laboratories are in charge of these biological analyses. The shellfish health surveillance system is thus well-organized in an institutional network of stakeholders, and their relationships are mandatorily defined (French Ministry of Agriculture, 2010).

The current regulatory definition of an increased shellfish mortality does not include objective criteria and mortality estimation is not straightforward: “,jncreased mortality" means unexplained mortalities significantly above the level of what is considered to be normal for the farm or mollusc farming area in question under prevailing conditions. What is considered to be increased mortality shall be decided in cooperation between the farmer and the 
competent authority” (European Union, 2006). Also, mortality detection is limited by the difficulties of gaining access to the animals, which limits the opportunities for close observation. In shellfish farming, access to the production areas is challenging because of the tide cycle and meteorological conditions. A shellfish farm is constituted of multiple leasing grounds that can be located in different production areas (see Figure 1 as an example), and of on land premise where shellfish are processed and packaged for further human consumption. A production area is geographically defined and is constituted by multiple leasing grounds, belonging to different shellfish farmers. The on land premises are clustered in harbours located near the production areas because boats are needed to access the different production areas. Thus, a single production area is shared by multiple shellfish farmers who can come from multiple harbours, and a single harbour gathers shellfish farmers that have leasing grounds in multiple production areas. As husbandry practices of shellfish are routined by the tide cycle, shellfish farmers are present on the production areas at the same time and every single farmer can observe the animals, which belong to him/her or to his/her neighbours. Thus, the possibility to detect an increased shellfish mortality in a given production area is similar for every single farmer. If a farmer observes shellfish mortality, he/she can easily share and compare the information with others during work on the production area and when going back to the harbour. These contribute to shape the social relationships of the shellfish farmers ${ }^{\text {ee }}$ communities. Social relationships between individual shellfish farmers and their social groups may influence their decision to notify mortality. The concept of social capital refers to the norms and networks that enable people to act collectively (Woolcock and Narayan, 2000). This notably includes trust, reciprocity and information network among the farming community. Also, mutual confidence and trust must exist between stakeholders in the reporting chain for effective surveillance (World Bank, 2010). The French shellfish farming is legally organised (Code rural et de la pêche maritime). In each producing region, the regional 
committee for shellfish farming (Comité Régional Conchylicole - CRC) is a recognized body of public law which aims at accompanying, defending, representing, communicating and promoting the shellfish farming activities. Each shellfish farmer must become a member of the $\mathrm{CRC}$ and can become a member of a syndicate, which is often structured by geographical area and sometimes by shellfish species. Each syndicate elects a representative, who is a farmer, to sit at the CRC board. The CRC board is appointed by law. It is led by a president and organised in commissions dedicated to species, which are chaired by elected vicepresidents. During monthly meetings of the CRC board, information as regards shellfish mortality reported in each syndicate is shared so the CRC board has a global view of the situation in its producing region. These meetings also include a representative of each of the stakeholders at the local level.

When a listed or emerging pathogen is detected, control strategies that are usually implemented in terrestrial animal productions (e.g., treatment, vaccination, disinfection) are not fully applicable in the marine environment because of its openness and connectivity and shellfish lack of true adaptive immune system (Renault, 2009; Pernet et al., 2016). One of the only applicable mitigation strategies in shellfish production is the timely restriction of the movement of animals in the concerned producing region (European Union, 2006; French Ministry of Agriculture, 2008) to limit the spread of the pathogen. The consequences of such measures are thus collective, involving the entire producing region, which have an economic impact.

In March and April 2014, mass mortality outbreaks were reported in mussels in France, Pertuis Charentais (Garcia et al., 2015, and Figure 1), which caused severe losses to the mussel industry (13 million euros, European Commission, 2015). The Repamo network 
conducted investigations, and a multi-disciplinary analytic approach was rapidly implemented to better understand this phenomenon, namely, research activities involving pathogen detection, description of environmental factors and animal physiology (Béchemin et al., 2015). An emerging infectious disease (EID) involving pathotypes of Vibrio splendidus species in particular was described by the NRL, which was supported by the experimental reproduction of mussel mortality using biological material from Repamo samples (Garcia et al., 2015). No mitigation measures were implemented, and financial compensation (7.25 million euros) involving different aid instruments was distributed to the impacted mussel farmers in 2014 (European Commission, 2015). This newly described EID spread along the coastline. In March and April 2015, similar mortality outbreaks were reported in mussels in another French production region (Garcia et al., 2016).

Earlier detection of the mortality outbreaks would have led to an earlier recognition of an EID outbreak. This would have provided an opportunity to limit its spread and the related mussel losses by applying timely mitigation measures in impacted water bodies, such as animal movement restrictions or movement management based on pathogen screening. Therefore, a study was conducted with the main objective of assessing the relevance and feasibility of an enhanced clinical surveillance based on the mussel farmers ${ }^{\text {ee }}$ network to improve the early detection of mussel mortality outbreaks. Secondary objectives were to collate the farmers ${ }^{\text {ee }}$ perceptions related to mussel mortality to aid in describing the outbreak and in developing hypotheses during the outbreak investigation. 


\section{Material and methods}

\subsection{Study population and case definition}

The study population included all of the mussels, including Mytilus edulis or blue mussel, of Pertuis Charentais (Figure 1). This region produced 26\% of the total French mussel production in 2012 (59 781 tons) and included 164 out of 618 French farms producing blue mussels (National census of shellfish farming, Recensement de la conchyliculture, for 2012). Mussel production is dispatched between 18 production areas, which are defined by a specific name and characterized by the farming technique, i.e., longlines that are suspended vertically in the water under a fixed or floating plastic buoy and fully immerged, wooden stakes or "bouchots" driven into intertidal ground or natural beds from which mussels are taken (Prou and Goulletquer, 2002), and the step of production (seed collecting or growing area). Wild mussels can also grow on farming structures for other shellfish, e.g., oysters. Mussel farming begins with the collection of mussel seeds from coconut fibre ropes placed in seed collecting areas, at the end of the winter. The ropes are collected and transferred to growing areas, either on wooden stakes or on longlines, generally between May and July. Harvesting takes place when mussels have reach their marketable size (Prou and Goulletquer, 2002), 12 to 18 months later.

A case was defined as one or more reports of increased mortality observed in mussels by farmers in a single production area during one week. The regulatory definition of an „increased mortality" was applied: “unexplained mortalities significantly above the level of what is considered to be normal for the farm or mollusc farming area in question under the prevailing conditions" (European Union, 2006). The multiple farmers sharing a single production area provided increased opportunity for reporting of an increased mortality in this given production area. 


\subsection{Study design}

The intended respondent was the vice-president of the CRC in charge of the mussel commission. This person is a key informant, playing a central role in the information network of the mussel farmers to obtain a rapid and overall census and monitor the distribution of cases. The mussel farming practices and organisation are based on mutual confidence and trust. As a representative of a syndicate, this person was elected to represent the mussel farmers of the region at the CRC board and to the other stakeholders. As all mussel farmers of the region are mandatorily members of the $\mathrm{CRC}$, the entire mussel farmers ${ }^{\text {ee }}$ community of the region is covered by this relationship. The respondent collects information about the mussel mortality situation during the monthly meetings of the mussel commission of the CRC board, where the mussel production situation is discussed and informed by the representatives of each syndicate representing all mussel production areas of the region. As a mussel farmer, this person also collects and shares information simultaneously with the other farmers sharing the same production areas or the same harbour. In addition, as the reference person for mussels in the region, this person is also involved into information collection and sharing both actively and passively at the region level for the entire mussel farmers ${ }^{\text {ee }}$ community. Information collection and sharing about mussel mortality is mainly conveyed by timely telephone calls and conversations at the harbour, when farmers return from the field work (Durivaud, Personal communication).

The study was prospective and gradually monitored the new cases identified through weekly telephone interviews of the same respondent that were conducted from the $19^{\text {th }}$ of March to $22^{\text {nd }}$ of April 2014. Monitoring began two days after the first notification of mussel mortality to the DDTM, which was further investigated by the Repamo network. Monitoring lasted 
until no incident nor prevalent case was observed within a subsequent tide cycle to ensure that the access conditions to mussels would not bias their observation and prevent to detect any case. A time frame of one week was chosen to detect new cases each time a mussel farmer accessed a production area, as the fieldwork organization is based on a tide cycle that is 14 days long and is split between spring and neap tides of seven-day intervals each. Farmers have access to the mussels during the spring tide when the "bouchots" are out of the water. They work at the on land premise during neap tide. Information sharing and flow can occur during both half tides. This time frame was also intended to improve the recall and accuracy of responses by providing a memorable event and time landmark on which to base questioning.

\subsection{Data collection}

Only one experienced interviewer (JP), who is involved in the monthly meetings of the CRC board as the representative of the scientific stakeholders, conducted data collection through semi-structured phone interviews to ensure the standardization of the interview method and to improve the acceptance of the repeated telephone calls.

A semi-structured questionnaire was used to guide the interviews and allow themes to emerge from the participant narratives. Systematic collected data were composed of pre-determined themes such as the space and time location of the cases, and species of the concerned shellfish. Additional themes were also collected such as the description of the extent of the mortality, observations about the environment, and comments and perceptions of the overall phenomenon by the respondent. All of the interviews were audio-recorded with the respondent $\mathrm{e}^{\mathrm{e}} \mathrm{s}$ authorization and were transcribed in full following the interview into Microsoft Word(C) using Dragon NaturallySpeaking( software version 13 for vocal recognition. 
Data from the institutional surveillance shellfish health system were retrospectively retrieved, i.e., mortality notifications to the DDTM and those further investigated by the Repamo network in Pertuis Charentais during the study period.

\subsection{Data analysis}

The analytic approach was based on the phenomenology research tradition, which describes the "subjective reality" of an event as perceived by the study population. Phenomenology research is the study of a phenomenon (Schutz, 1962), of the ways we experience things, and the meanings that things have in our experience. A four-step analysis procedure is recommended (Giorgi, 1985) that involves obtaining a total impression, identifying meaning units (i.e., categories), abstracting the content of individual meaning units (i.e., themes), and summarizing their importance.

First, qualitative data were described using content analysis (Elo and Kyngas, 2008), which allows both inductive and deductive reasoning to identify themes and associated categories as well as the quantitative count of the themes and categories (Downe-Wamboldt, 1992). Interview transcripts were analysed by both authors who read through the transcripts several times to familiarize themselves with the raw data and to identify key themes and issues. Some themes (e.g., space and time location, impacted animals) were pre-determined as these variables are usual descriptors of an outbreak. Other themes (e.g., description of the extent of the mortality, perception of the situation, environment description) were developed from the data using an inductive approach code the responses, which was driven by the data itself and not by pre-determined categories (Elo and Kyngas, 2008). Response categories were then 
grouped together by themes. Any discrepancies in the coding were resolved by discussion among the authors.

The quantitative counts of pre-determined themes provided the total number of cases in time and space.

To describe the outbreak in space and time, an epidemic curve and weekly census of incident cases were built using the pre-determined themes and related categories, such as time and space location.

To evaluate the timeliness of the detection of mussel mortality by different information routes, the resulting findings were compared with data that were retrospectively available from the mortality notifications to the DDTM (weekly number of notifications) and the Repamo network (weekly number of investigated notifications ) in Pertuis Charentais.

Second, raw interview transcripts were analysed by linguistic analysis using a TXM computer-based text analysis tool (Heiden, 2010). Semantic fields, vocabulary and toponymy elements were identified, and counts of the frequency of words were extracted. Appendix A shows the translation of French words into English (WordReference English-French Dictionary® 2015 and Prou and Goulletquer, 2002, for farming structures). This analysis enabled a description of how the farmers perceive a mortality event in mussels.

Third, qualitative data were interpreted using thematic analysis to identity the latent content of data (Braun and Clarke, 2006). Both authors interpreted the overall data collected to explain the phenomenon of mussel mortality through analytical narratives. Relationships between themes and the development of hypotheses associated with the explanation process of mussel mortality were investigated through graphical representation of the identified themes and associated categories (See Appendix B for an example). These enabled a parallel to be drawn 
between ideas and to organize them into a series for a deeper analysis of what the story relayed, e.g., how the environmental factors favoured the mortality of mussels. Discrepancies in coding, in the interpretation of findings and in emerging hypotheses were discussed and adjusted accordingly. These findings were graphically expressed in a conceptual map using IHMC CMapTools@ (Cañas et al., 2005).

\section{Results}

In total, 6 prospective telephone interviews were conducted weekly for a six-week period, between $19^{\text {th }}$ March and $22^{\text {nd }}$ April 2014. The interviews were between 8 and 18 minutes long. Transcription and analysis of interviews took on average four times the interview length.

\subsection{Position of the respondent in the mussel farmers "infrmation network}

The central position of the respondent in the communication network for the mussel farmers ${ }^{\text {ee }}$ community was assessed several times:

"In Marsilly [...], one of my colleagues, who called me this morning during the tide, told me that he did not see dead mussels last week" (2 ${ }^{\text {nd }}$ April)

"Tomorrow morning, we will go to see the bouchots [...] I will have a complete view of the area of Pointe de l"Aiguilon and Chatelaillon because we are going to Chatelaillon and other colleagues will go to the Pointe de l"Aiguilon" (10 ${ }^{\text {th }}$ April)

"In the Baie d"Yves, this morning, [colleague"s name] was telling me that mortality has ceased" $\left(10^{\text {th }}\right.$ April)

"In Antioche sluice, guys were at the tide a bit earlier, they didn"t noice all that much mortality" (15 $5^{\text {th }}$ April)

\subsection{Description of the outbreak}

\subsubsection{Time and space distribution of the cases}


In total, 16 cases of mussel mortality were observed between the $4^{\text {th }}$ of March (week 2014-9) and the $22^{\text {nd }}$ of April 2014 (week 2014-15), representing 89\% of the production areas . Incident cases peaked in week 2014-11 and a second time in week 2014-14 (Figure 2). The outbreak lasted for 6 weeks. The median number of weekly incident cases observed by the farmers ${ }^{\text {ee }}$ network was 1 incident case, with a range from 0 to 5 incident cases. The median number of weekly prevalent cases observed by the farmers ${ }^{\text {ee }}$ network was 3 prevalent cases, with a range from 0 to 11 prevalent cases (Figure 3).

Figure 3 shows the spatiotemporal distribution of the observed cases. The first cases were observed in the North of the Pertuis Charentais and almost simultaneously in all of the production areas . In the South, cases were observed later, and two production areas were not impacted. Incidence proportions, or attack rates, were higher in the Northern water bodies than in the Southern ones (Table 2).

\subsubsection{Description of an increased mussel mortality according to the farmers}

The respondent described an increased mussel mortality using quantitative and qualitative criteria. The extent of the mortality was characterized by the proportion of dead animals. A threshold of 5\% seemed to distinguish a normal mortality from an abnormal mortality: “When we say,,Worried", we exceed 30\%. Mortality, for us, is over 5... $6 \%$ [...]. Above that, we start to worry. At 20\%, we know that this is no longer profitable and it becomes worrisome." (2 $2^{\text {nd }}$ April)

Farmers estimated this proportion by counting the number of live mussels on a section of the wooden stake or longline and generalizing this count to encompass the productivity of the entire wooden stake or longline. The difference between the estimated and expected productivity determined the estimate of the proportion of dead animals. 
The qualitative description of an increase in mussel mortality used different semantic fields (Table 1). This description was not limited to animal health-related concepts and notably included elements pertaining to seawater quality and farming structures. In particular, mussels could be qualified as alive, moribund (i.e., gaping but still alive) or dead, which is not a binary phenomenon (alive-dead). The observation of empty shells or rotting shellfish flesh was evoked to localize the mortality within a certain time frame:

"After five days, the flesh is out of the shell" (19 ${ }^{\text {th }}$ March)

"In the Breton sluice, there is on-going mortality. It"s ongoing in areas where there was 6070\%. In Pointe de l"Aiguillon, there are mussels with flesh still inside" (15 ${ }^{\text {th }}$ April)

Surrounding seawater was often mentioned in combination with the farming structures:

"Only mussels at the surface, on the buoys, are really highly impacted, up to 50\%" ( 9 th April) The spatial location included the depth of the mussels, with the farming height being a dimension that was frequently considered:

"It"s [mortality] on the whole height, on the whole height, whereas last week or last tide, we only saw it on the bottom [of the bouchot] $\left(2^{\text {nd }}\right.$ April $)$

The word "tide" was most commonly used to locate observations in time (30 times; 2.4 per thousand of the words).

\subsection{Hypothesis generation}

The cognitive map (Figure 4) shows the hypothesis generation that emerged from the six successive interviews. Very detailed scenarios were developed with regard to the processes that caused the mussel mortality, emphasizing the links between climatic factors, water quality and mussel physiology. In particular, pathogens were not believed to be the initial cause of the mortality outbreak, and an overall view of the health of the coastal marine 
ecosystem was drawn. The accidental or short-term causes were emphasized, such as brutal degradation of the marine environment that damaged farming, or discharges of freshwater in the coastal environment due to heavy rainfalls.

\subsection{Comparison of information sources for outbreak detection}

The first case was observed by the farmers "e network in week 2014-10, and a rise in the number of cases was detected the following week (Figure 2). The first notifications to the DDTM of mussel mortality occurred in week 2014-12, and some claims were further investigated by the Repamo network the same week ( 3 out of 10 notifications). 


\section{Discussion}

This study is the first to provide insights into the relevance and feasibility of an enhanced clinical surveillance of mussel mortality based on the mussel farmers ${ }^{e e}$ network.

\subsection{Study methodological quality}

The recommendations that ensure a good methodological quality of qualitative research (Cohen and Crabtree, 2006) were applied. The evaluative criteria (Mays and Pope, 1995; Malterud, 2001; Cohen and Crabtree, 2008) that were applied with the phenomenology research tradition are further discussed.

The internal validity, or credibility, of the present study was ensured by the use of a case definition that relied on the mussel farmer's own definition of an increased mussel mortality. This was consistent with the study of a phenomenon (Schutz, 1962) in that it relied on the "subjective reality" of an event as perceived by the study population. It is also interesting to note that this rationale behind the case definition is consistent with the definition of an „,increased mortality ${ }^{e e}$ that provided by the current European regulation at the ,mollusc farming area $^{\text {ee }}$ level(European Union, 2006). The multiple farmers sharing a single production area provided redundancy and increased opportunity for reporting of an increased mortality event in this given production area. Defining the case at the production area level has a high sensitivity but lower specificity to minimise the risk of missing any cases and to favour early detection of a potential EID. Also, the mussel farming practices and organisation are based on mutual confidence and trust. These guarantee the trustworthiness a collective perception of abnormality, as well as the quality (accuracy and timeliness) of the data conveyed by the network and centralized by the respondent. 
In addition, because the interviews were conducted weekly and simultaneously with the mortality outbreak, informal member checking (Lincoln and Guba, 1985) arose several times during the normal course of the conversation. For example, the finding related to the two peaks of cases was read back to the interviewee on the 22th April (Week 2014-17) to see if the analysis and interpretation of the data by the researchers were regarded as a reasonable account of his experience:

-Interviewer: "there was a first peak [of mussel mortalities] with new impacted areas, then it decreased [...], and then there was a second little spurt."

-Respondent: "Exactly, it"s exactly that because we thought that the area of [...] Pointe de la Roche [...] was impacted from 30 to $40 \%$ at the end of the spring tide, and we only had [empty shells] and during neap tide this started again until 100\% were moribund mussels."

The external validity, or transferability, of the present study was difficult to formally assess. The use of a single key informant with access to relevant sources of knowledge for data collection was appropriate in the present study because the information network for the French mussel farmers ${ }^{\text {ee }}$ community is well-structured and highly centralized in Pertuis Charentais. Here, the information flow and sharing were shaped by the mussel farming organisation (syndicates and CRC), the simultaneous presence of the farmers in the shared production areas and in the harbours due to the tide cycles. However, the generalizability of such sampling strategy to other shellfish communities depends on the structure of their information flow. Understanding the human dimension affecting trust, reciprocity and information network of shellfish farming communities is paramount (Brugere et al., 2016). Social capital, which includes these previous elements, as well as norms, formal and informal membership of groups, collectives and networks (Woolcock and Narayan, 2000), is not yet formally described for shellfish farmersee communities. 
The reliability of our approach to data analysis was ensured by the qualitative check of intercoder reliability (Tinsley and Weiss, 2000) at different stages, which refers to the extent to which more than one coder independently classifies material in the same way as another coder. Transcripts were coded independently by the two authors. The themes and related categories were then compared and discussed to ensure the coherence of the coding judgements. The interpretation of the findings and emerging causal hypotheses were also analysed separately by the two authors and regularly discussed during the process of analysis.

Researcher bias, or reflexivity, was accounted for during the data collection and analysis and was minimized as much as possible. Only one interviewer collected data to enhance the high quality of the collected data. However, the researcher's preconception of the context and angle of investigation can shape the qualitative research process (Malterud, 2001). Thus, the researcher's subjectivity was limited during data collection by the use of a semi-structured questionnaire, for example, by systematically identifying the pre-determined common outbreak descriptors, such as the location in time and space of the cases. The influence of the researcher was limited during data analysis by the independent coding of the transcripts by the two authors. Moreover, to show that the analysis was supported by the data, the presentation of results included a combination of quotations from transcripts, a quantitative summary of the cases in time and space, and the word counts used by the respondent.

Different qualitative research approaches were combined for data analysis. Content analysis enabled quantification of the data, and thematic analysis allowed for the identification of patterns within the data (Vaismoradi et al., 2013), notably leading to the generation of causal hypotheses. Both deductive and inductive modalities were applied. For practical reasons, the 
use of pre-determined themes was essential to enable prompt reaction in cases of disease suspicion. A deductive approach was thus used to compare the pre-determined themes or associated categories (Elo and Kyngas, 2008) on current outbreak descriptions over time and space. The use of an inductive approach enabled the identification of hypotheses or other relevant information directly from the text data when there were no previous studies dealing with the phenomenon (Hsieh and Shannon, 2005). These complementary choices allowed researchers to optimize the amount of energy and time spent on the process of data gathering and analysis.

Thus, as exploratory qualitative research, we believe that our study is methodologically robust and rigorous and provides high quality data that produced high quality findings.

\subsection{Early outbreak detection}

Telephone interviews detected the mussel mortality outbreak through the farmers ${ }^{\text {ee }}$ network one week before the institutional shellfish health surveillance system. Rapid sharing of information on disease spread along networks of farmers, which does not pass through a formal surveillance system, has also been described in other communities, e.g., the Thai cockfighting community (Paul et al., 2015). In marine open systems, diseases spread rapidly and potentially widely due to a lack of barriers to dispersal and to ocean currents (McCallum et al., 2003). Thus, a gain of one week in detecting an outbreak is valuable if measures can be undertaken to limit its spatial spread.

The clinical surveillance of shellfish mortality consists of two distinct stages: detection that relies on the observation of an increased mortality and the alert that is launched as a result of the notification of mortality. According to the current European regulation, the surveillance 
case definition is simple, but quite subjective (European Union, 2006). The first stage, i.e., mortality detection, is a function of the farmeres watchfulness of his animals. This is mainly challenged by difficulties in gaining access to the shellfish because of the tide cycle and meteorological conditions. The second stage, i.e., mortality notification, depends on the anomaly perceived by the observer because no objective criteria are given by the current regulation. This supposes that the observation can be compared to a reference or to a previous situation to be able to conclude that the observation is abnormal. If the observer concludes that mortality is abnormal, the observation turns into a detection. The present study provided insights into the farmers ${ }^{e e}$ perceptions of abnormal (i.e., increased) mortality in mussels. This description was not limited to animal health-related concepts and notably included elements pertaining to water quality and farming structures. These perceptions differed from those of oyster farmers working in the same geographic region, who only used animal-based observations to describe an abnormal mortality in oysters (Carlier et al., 2013; Lupo et al., 2014). Also, a threshold of 5\% was reported to distinguish abnormal from normal mortality, using a rough estimation of proportion of dead mussels. This should be used as an order of magnitude, as accurate recording of mortality is challenging in the aquatic environment (Peeler and Taylor, 2011; Lupo et al., 2012).

Consequently, this detection should become a notification to the DDTM (French Ministry of Agriculture, 2008) as the second stage of the surveillance. A previous study showed that most oyster farmers first reported their observations to their colleagues, even if immediate notification to the DDTM was mandatory (Lupo et al., 2014). The improved timeliness of the detection of the farmers ${ }^{\text {ee }}$ network compared to the institutional surveillance network observed in the present study is consistent with this previous finding. In shellfish production, the alert onset is reinforced if it is shared by multiple farmers. Effectively, for a given shellfish species, farmers have comparable husbandry schemes so that multiple farmers are present 
simultaneously in the same production area, despite the challenge of gaining access due to tide cycles and meteorological conditions. The individual perceptions of abnormality can then quickly turn into a collective perception that sets an alert. Thus, the decision to notify authorities about shellfish mortality is triggered by the synchronized observation of abnormal mortality by multiple farmers in a same production area. This process differs from the terrestrial productions in which a single individual notification can confidently launch an alert, for example, in the case of suspicion of foot and mouth disease (European Union, 2003).

\subsection{Outbreak description}

Prospective telephone interviews collected data that led to a detailed description of the mussel mortality outbreak. Pre-determined themes, such as the space and time location of the cases, were also easily collected to describe the epidemiological situation using common indicators. In particular, the shape of the epidemic curve shows a sudden rise in the number of cases in a short period of time and a secondary peak two weeks later. The first peak occurred in the North of the Pertuis Charentais and the second peak in the South. These could evoke an exposure to a common point source that may be an infectious disease or chemical compounds. The epidemic curve may also provide information about the mode of transmission of the source of the outbreak. Within the context of an open marine environment, the second peak may evoke either the time taken to transport the source by the marine currents to reach new susceptible mussel populations in new production areas or the delay in reaching favourable environmental conditions between the production areas or water bodies for the impact of the source on the mussels if the source was already present in the seawater. These hypotheses should be further assessed by assessing the transit time of the seawater circulation modelling in the Pertuis Charentais (Lazure et al., 2009) under the observed meteorological conditions. 


\subsection{Hypothesis generation}

In addition to the description of the outbreak, which may assist with generating hypotheses regarding the source and mode of transmission, the phone interviews collected background elements of the mussel mortality outbreak and free observations, which integrate a global view of the health and disturbance of the coastal marine ecosystem. Detailed hypotheses were generated with regard to the presumed causative processes, but abnormal mussel mortality was considered to be one indicator among others (such as climatic factors, seawater quality, presence of pathogens or mussel physiology) to describe the disturbance in the marine ecosystem. Eliciting this knowledge as a surveillance finding could have helped to develop more integrated investigations. Effectively, concomitant analytical studies investigated different relevant, but separate, hypotheses, such as the link between the spatiotemporal evolution of mussel mortality and (1) a selection of oceanographic variations, i.e., the seawater temperature, salinity turbidity, and chlorophyll a proxy, during the previous winter (Polsenaere et al., 2015); (2) the involvement of known or emerging pathogens (Garcia et al., 2015); or (3) an alteration of mussel physiology, i.e., energetic reserves, nutritional and metabolic status (Béchemin et al., 2015). To date, these separate approaches have not drawn straightforward conclusions on an integrated scale.

\subsection{Feasibility considerations}

This alternative method of surveillance data collection is an example of participatory approaches to disease surveillance. Participatory disease surveillance is a proven and flexible approach to active disease surveillance that has been adapted to a wide variety of settings and is used to strengthen disease surveillance in many countries (Jost et al., 2007). This approach requires out-reach to farmers to obtain relevant data through active surveillance (Jost et al., 2007). 
Such an enhanced clinical surveillance of mussel mortality through regular and short (no more than 20 minutes) telephone interviews targeting the mussel farmers ${ }^{\text {ee }}$ network seems feasible. The use of pre-determined themes to collect enabled the rapid streamlined analysis of the interviews to describe the outbreak. Therefore, the description could be easily updated every week. The use of a time step of one week was consistent with the constraints due to tide cycles and the time required transcribing and analysing interviews for content. Also, the particular structure of the mussel farmers ${ }^{e e}$ community-based information network allowed important time saving. Instead of conducting multiple interviews, only one person was repeatedly interviewed during six weeks to collect the data. As a central representative of the mussel farmers ${ }^{e e}$ network in Pertuis Charentais, this person could transmit the collective perception about the mussel mortality outbreak, which was built on individual perceptions and shared among the mussel farmers ${ }^{e e}$ community. Continuous data collection was made possible because of the interviewer"s legitimacy and current long-term involvement in regular meetings of the CRC board as the representative of the scientific stakeholder. Similar findings were described in Vietnam, where the commune veterinarian served as the interface between the formal and the informal surveillance networks for a highly pathogenic avian influenza (Desvaux and Figuié, 2011). This underlines the necessity for in depth familiarity with the targeted community for surveillance purposes, which includes identifying the communitybased information network (Figuié et al., 2013; Goutard et al., 2015) and developing and maintaining a mutually trusting relationship between the interviewee and the interviewer (World Bank, 2010; Desvaux and Figuié, 2011; Goutard et al., 2015). The interview demands shared vocabulary and terminology, space knowledge, toponymy, practice, and so on between the interviewee and interviewer. Such relationships cannot be built during "war time". The 
present study illustrates that effective aquatic disease surveillance is about people (Brugere et al., 2016).

The main barrier to the use of an enhanced clinical surveillance method is the additional manpower required for conducting regular interviews and the additional data analysis needed in comparison with the current surveillance system. However, this additional time is compatible with the time step of the opportunities for close observation of mussels, constrained by the tide cycle. The frequency of interviews during the course of a year could be bi-monthly and structured around the tide cycles and the subsequent field-work organisation of the mussel farmers. This frequency may be increased when a mortality outbreak is detected by the farmers ${ }^{e e}$ network. However, even if time-consuming, by accounting for their observations and their perceptions, such an enhanced surveillance could improve the mussel farmers ${ }^{\text {ee }}$ watchfulness and favour their commitment.

\section{Conclusions}

This study demonstrated that weekly short telephone interviews targeting a key informant among the mussel farmers ${ }^{\text {ee }}$ network can collect data that fulfils all of the requirements for effective surveillance purposes. This farmer community-based enhanced surveillance method of data collection led to an improvement in the early detection of mussel mortality outbreak, enriched the outbreak description and was the basis for the development of hypotheses for epidemiological outbreak investigation. By taking into consideration their observations and perceptions, such an enhanced surveillance may improve the mussel farmers ${ }^{\text {ee }}$ watchfulness and enhance their commitment to sustainable shellfish health surveillance.

\section{Conflict of interest}

None. 


\section{Acknowledgments}

The authors thank the vice-president of mussel farming of the CRC Poitou-Charentes for his time and involvement, the Repamo network and DDTM17 for providing access to their data, and the French Ministry of Agriculture for funding this research project. The access to the data of the National census of shellfish farming was carried through the CASD dedicated to researchers authorized by the French Comité du secret statistique.

\section{References}

Béchemin, C., Soletchnik, P., Polsenaere, P., Le Moine, O., Pernet, F., Protat, M., Fuhrman, M., Quéré, C., Goulitquer, S., Corporeau, C., Lapègue, S., Travers, M.A., Morga, B., Garrigues, M., Garcia, C., Haffner, P., Dubreuil, C., Faury, N., Baillon, L., Baud, J.P., Renault, T., 2015. Episodes de mortalité massive de moules bleues observés en 2014 dans les Pertuis Charentais. Bull. Epid. Santé Anim. Alim. 67, 6-9. doi: bulletinepidemiologique.mag.anses.fr/sites/default/files/BEP-mg-BE67-art2.pdf

Braun, V., Clarke, V., 2006. Using thematic analysis in psychology. Qual. Res. Psychol. 3, 77-101. doi: http://dx.doi.org/10.1191/1478088706qp063oa

Brugere, C., Onuigbo, D., Morgan, K.L., 2016. People matter in animal disease surveillance: challenges and opportunities for the aquaculture sector. Aquaculture. doi: 10.1016/j.aquaculture.2016.04.012

Cañas, A.J., Carff, R., Hill, G., Carvalho, M., Arguedas, M., Eskridge, T.C., Lott, J., Carvajal, R., 2005. Concept Maps: Integrating Knowledge and Information Visualization. In: S.-O. Tergan and T. Keller (Ed.), Knowledge and Information Visualization: Searching for Synergies. Springer Lecture Notes in Computer Science, Heidelberg / New York. 
Carlier, M., Prou, J., Mille, D., Lupo, C., 2013. Oyster farmers' perception of spat mortality outbreaks: more a firm than a farm issue. In: Verheyen, K.L.P., Fourichon, C., and the SVEPM Executive Comittee (Ed.), Proceedings of the Society for Veterinary Epidemiology and Preventive Medecine, Madrid, Spain, 226-237.

Code rural et de la pêche maritime, Partie Législative, Livre IX : Pêche maritime et aquaculture marine, Titre 1er : Dispositions communes, Chapitre II : Organisations professionnelles, Section 2 : Organisation professionnelle de la conchyliculture.

Cohen, D., Crabtree, B., 2006. Qualitative Research Guidelines Project. http://www.qualres.org/HomeGuid-3868.html (accessed 09th November 2015).

Cohen, D.J., Crabtree, B.F., 2008. Evaluative Criteria for Qualitative Research in Health Care: Controversies and Recommendations. Ann. Fam. Med. 6, 331-339. doi: 10.1370/afm. 818

Desvaux, S., Figuié, M., 2011. Formal and informal surveillance systems: how to build bridges? Epidémiol. Santé Anim. 59-60, 352-355.

Downe-Wamboldt, B., 1992. Content analysis: method, applications, and issues. Health Care Women Int. 13, 313-321. doi: 10.1080/07399339209516006

Dufour, B., Hendrickx, P., 2009. The REPAMO in France. In: CIRAD FAO OIE and AEEMA (Ed.), Epidemiological surveillance in animal health. France, Paris, 261-270.

Elo, S., Kyngas, H., 2008. The qualitative content analysis process. J. Adv. Nurs. 62, 107115. doi: $10.1111 /$ j.1365-2648.2007.04569.x

European Commission, 2015. Aide d'Etat SA.39249(2014/N) - France - Mesures de soutien accordées aux entreprises mytilicoles touchées par la mortalité des moules au cours de l'année 2014. http://ec.europa.eu/competition/state aid/cases/253925/253925 1651137 89 2.pdf (accessed 26th January 2016). 
European Union, 2003. Council Directive 2003/85/EC of 29 September 2003 on Community measures for the control of foot-and-mouth disease repealing Directive 85/511/EEC and Decisions 89/531/EEC and 91/665/EEC and amending Directive 92/46/EEC. Official Journal of the European Union. 0001 - 0087.

European Union, 2006. Council Directive 2006/88/EC of 24 October 2006 on animal health requirements for aquaculture animals and products thereof, and on the prevention and control of certain diseases in aquatic animals. Official Journal of the European Union L328/14.

Figuié, M., Peyre, M., Binot, A., 2013. Surveillance of animal diseases: promoting the multiplicity of information networks. (Policy brief No. 23), Perspective. CIRAD, Montpellier, France.

French Ministry of Agriculture, 2008. Arrêté du 4 novembre 2008 relatif aux conditions de police sanitaire applicables aux animaux et aux produits d'aquaculture et relatif à la prévention de certaines maladies chez les animaux aquatiques et aux mesures de lutte contre ces maladies. JORF 07 novembre, 17077-17083.

French Ministry of Agriculture, 2010. Note de service DGAL/SDSPA/N2010-8072 du 17 mars 2010 relative à l'organisation des prélèvements de coquillages en cas de phénomène de hausse de la mortalité ou de signes de maladie des coquillages.

Garcia, C., Francois, C., Lupo, C., Arzul, I., Chollet, B., Dubreuil, C., Serpin, D., Baillon, L., Travers, M.-A., Tourbiez, D., Haffner, P., Morga, B., Faury, N., Garrigues, M., 2015. Epidemiologic Al report 2014 France. In, Annual Meeting of the National Reference Laboratories for Mollusc Diseases, Saintes, France.

Garcia, C., Osta Amigo, A., Fleury, E., Robert, S., Canier, L., Lupo, C., 2016. Epidemiologic Al report 2015 France. In, Annual Meeting of the National Reference Laboratories for Mollusc Diseases, Nantes, France. 
Giorgi, A., 1985. Sketch of a psychological phenomenological method. In: Giorgi A. (Ed.), Phenomenology and psychological research. Duquesne University Press, Pittsburgh, $8-22$.

Goutard, F.L., Binot, A., Duboz, R., Rasamoelina-Andriamanivo, H., Pedrono, M., Holl, D., Peyre, M.I., Cappelle, J., Chevalier, V., Figuie, M., Molia, S., Roger, F.L., 2015. How to reach the poor? Surveillance in low-income countries, lessons from experiences in Cambodia and Madagascar. Prev. Vet. Med. 120, 12-26. doi:

10.1016/j.prevetmed.2015.02.014

Heiden, S., 2010. The TXM Platform : Building Open-Source Textual Analysis Software Compatible with the TEI Encoding Scheme. In: K. I. Ryo Otoguro (Ed.), 24th Pacific Asia Conference on Language, Information and Computation - PACLIC24, Institute for Digital Enhancement of Cognitive Development, Waseda University, Sendai, Japan, 389-398.

Hsieh, H.F., Shannon, S.E., 2005. Three approaches to qualitative content analysis. Qual. Health Res. 15, 1277-1288. doi: 10.1177/1049732305276687

Jost, C.C., Mariner, J.C., Roeder, P.L., Sawitri, E., Macgregor-Skinner, G.J., 2007. Participatory epidemiology in disease surveillance and research. Rev. Sci. Tech. Int. Off. Epizoot. 26, 537-549.

Lazure, P., Garnier, V., Dumas, F., Herry, C., Chifflet, M., 2009. Development of a hydrodynamic model of the Bay of Biscay. Validation of hydrology. Cont. Shelf. Res. 29, 985-997. doi: 10.1016/j.csr.2008.12.017

Lincoln, Y.S., Guba, E.G., 1985. Naturalistic Inquiry. Sage Publications Newbury Park, CA. Lupo, C., François, C., Arzul, I., Garcia, C., Joly, J.P., Renault, T., 2012. Défis de la surveillance des maladies chez les coquillages marins en France. Epidemiol. Sant. Anim. 62, 27-42. 
Lupo, C., Osta Amigo, A., Mandard, Y.V., Peroz, C., Renault, T., 2014. Improving early detection of exotic or emergent oyster diseases in France: identifying factors associated with shellfish farmer reporting behaviour of oyster mortality. Prev. Vet. Med. 116, 168-182. doi: 10.1016/j.prevetmed.2014.05.002

Malterud, K., 2001. Qualitative research: standards, challenges, and guidelines. Lancet 358, 483-488. doi: 10.1016/S0140-6736(01)05627-6

Mays, N., Pope, C., 1995. Rigour and Qualitative Research. Brit. Med. J. 311, 109-112. doi: http://dx.doi.org/10.1136/bmj.311.6997.109

McCallum, H., Harvell, D., Dobson, A., 2003. Rates of spread of marine pathogens. Ecol. Lett. 6, 1062-1067. doi: 10.1046/j.1461-0248.2003.00545.x

OIE, 2015. Aquatic Animal Health Code. http://www.oie.int/en/international-standardsetting/aquatic-code/access-online/ (accessed 07 june 2016).

Paul, M.C., Figuie, M., Kovitvadhi, A., Valeix, S., Wongnarkpet, S., Poolkhet, C., Kasemsuwan, S., Ducrot, C., Roger, F., Binot, A., 2015. Collective resistance to HPAI H5N1 surveillance in the Thai cockfighting community: Insights from a social anthropology study. Prev. Vet. Med. 120, 106-114. doi:

10.1016/j.prevetmed.2015.02.021

Peeler, E.J., Taylor, N.G.H., 2011. The application of epidemiology in aquatic animal health opportunities and challenges. Vet. Res. 42: 94. doi: 10.1186/1297-9716-42-94

Pernet, F., Lupo, C., Bacher, C., Whittington, R.J., 2016. Infectious diseases in oyster aquaculture require a new integrated approach. Phil. Trans. R. Soc. B. 20150213. doi: http://dx.doi.org/10.1098/rstb.2015.0213

Polsenaere, P., Soletchnik, P., Le Moine, O., Robert, S., Gohin, F., Stanisiere, J.-Y., Dumas, F., Bechemin, C., 2015. Relationships between winter environmental variations and 
the blue mussel mortality event observed in the Pertuis Charentais (French Atlantic coastal zone). In, ASLO Aquatic Sciences Meeting, Granada, Spain.

Prou, J., Goulletquer, P., 2002. The French mussel industry: present status and perspectives. Bull. Aquacult. Assoc. Canada 102, 17-23. Open Access version : http://archimer.ifremer.fr/doc/00000/02802/.

Renault, T., 2009. Trends and perspectives in preventing and controlling infectious diseases in molluscs. In: T.T Nakamura (Ed.), Aquaculture Research Progress. Nova Publisher, 99-126.

Schutz, A., 1962. Collected papers, volumes 1-3, The Hague, Martinus Nijhoff.

Tinsley, H.E.A., Weiss, D.J., 2000. Interrater reliability and agreement. In: H. E. A. Tinsley \& S. D. Brown (Ed.), Handbook of Applied Multivariate Statistics and Mathematical Modeling. Academic Press, San Diego, CA, 95-124.

Vaismoradi, M., Turunen, H., Bondas, T., 2013. Content analysis and thematic analysis: Implications for conducting a qualitative descriptive study. Nurs. Health Sci. 15, 398405. doi: $10.1111 /$ nhs. 12048

Woolcock, M., Narayan, D., 2000. Social capital: Implications for development theory, research, and policy. World Bank Res Obser 15, 225-249.

World Bank, 2010. People, Pathogens and Our Planet. Volume 1: Towards a One Health approach for controlling zoonotic diseases. Report N 50833-GLB. World Bank, Washington DC, 56. 
Table 1. Semantic fields and related word counts used by the key informant of the mussel farmers $^{\text {ee }}$ network information to describe increased mortality in mussels, Pertuis Charentais, France, 2014 
Table 2. Water-body specific incidence proportion of cases of mussel mortality observed by the farmers ${ }^{\text {ee }}$ network in Pertuis Charentais, France, 2014 
Figure 1. Pertuis Charentais (grey territory), with the mussel production areas in dark grey and coastal water bodies ${ }^{1}$

\footnotetext{
${ }^{1}$ As defined by the EU Water Framework Directive, i.e. Directive 2000/60/EC of the European Parliament and of the Council establishing a framework for the Community action in the field of water policy
} 
Figure 2. Epidemic curves of the weekly number of incident cases of mussel mortality observed by the mussel farmers ${ }^{\text {ee }}$ network (black bars), mortality notifications to the DDTM (white bars) and Repamo network investigations (grey bars). The tide cycle is represented by the spotted line ${ }^{2}$. Pertuis Charentais, France, 2014

\footnotetext{
${ }^{2}$ Spring tide is defined by tide coefficient $>70$, and neap tide is defined by tide coefficient $<70$. Tide coefficient is a measure of the amplitude of the difference in height between the consecutive high tide and low tide in a given area. It is defined on a scale from 0 to 120 . Tide coefficient is commonly used by French shellfish stakeholders.
} 
Figure 3. Spatial distribution of cases of mussel mortality observed by the mussel farmers ${ }^{\text {ee }}$ network in Pertuis Charentais, France, 2014, grouped by coastal water bodies ${ }^{3}$ and ordered from north to south. The grey squares represent prevalent cases.

\footnotetext{
${ }^{3}$ As defined by the EU Water Framework Directive, i.e. Directive 2000/60/EC of the European Parliament and of the Council establishing a framework for the Community action in the field of water policy
} 
Figure 4. Cognitive map of the explanation of the causal hypothesis for mussel mortality generated during the six successive interviews of the key informant of the mussel farmers ${ }^{\text {ce }}$ community, Pertuis Charentais, France, 2014 
Table 1. Semantic fields and related word counts used by the key informant of the mussel farmers $^{\text {ee }}$ network information to describe increased mortality in mussels, Pertuis Charentais, France, 2014

Semantic Word

field

\section{Count (per thousand)}

\begin{tabular}{lllllll}
\hline All & $\mathrm{N}^{\circ} 1$ & $\mathrm{~N}^{\circ} 2$ & $\mathrm{~N}^{\circ} 3$ & $\mathrm{~N}^{\circ} 4$ & $\mathrm{~N}^{\circ} 5$ & $\mathrm{~N}^{\circ} 6$
\end{tabular}

interviews

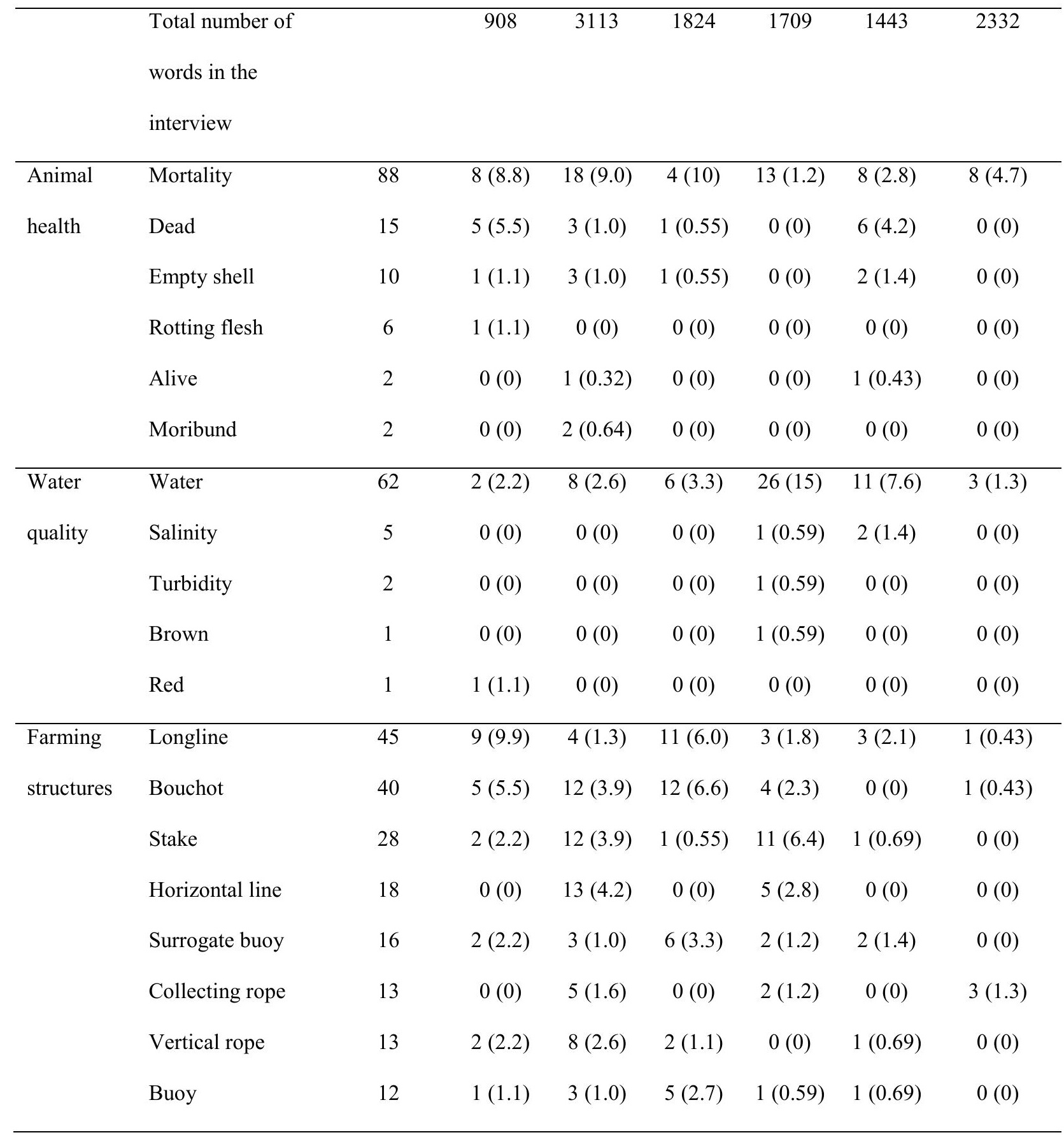




\begin{tabular}{|c|c|c|c|c|c|c|c|c|}
\hline & Tube of seed & 8 & $0(0)$ & $3(1.0)$ & $0(0)$ & $0(0)$ & $0(0)$ & $0(0)$ \\
\hline Animal & Mussel & 94 & $8(8.8)$ & $28(9.0)$ & $19(10)$ & $2(1.2)$ & $4(2.8)$ & $11(4.7)$ \\
\hline \multirow[t]{9}{*}{ species } & Oyster & 12 & $1(1.1)$ & $2(0.64)$ & $1(0.55)$ & $1(0.59)$ & $5(3.5)$ & $2(0.85)$ \\
\hline & Sea urchin & 5 & $0(0)$ & $0(0)$ & $0(0)$ & $0(0)$ & $0(0)$ & $0(0)$ \\
\hline & Crabs & 4 & $0(0)$ & $1(0.32)$ & $0(0)$ & $3(1.8)$ & $0(0)$ & $0(0)$ \\
\hline & Sand-star & 3 & $0(0)$ & $0(0)$ & $0(0)$ & $3(1.8)$ & $0(0)$ & $0(0)$ \\
\hline & Scallop-like & 2 & $0(0)$ & $1(0.32)$ & $0(0)$ & $0(0)$ & $1(0.69)$ & $0(0)$ \\
\hline & Slipper shell & 2 & $0(0)$ & $0(0)$ & $0(0)$ & $0(0)$ & $2(1.4)$ & $0(0)$ \\
\hline & Sea-star & 2 & $0(0)$ & $0(0)$ & $0(0)$ & $1(0.59)$ & $0(0)$ & $1(0.43)$ \\
\hline & Peppery furrow & 2 & $0(0)$ & $0(0)$ & $0(0)$ & $0(0)$ & $2(1.4)$ & $0(0)$ \\
\hline & shell & & & & & & & \\
\hline \multirow[t]{6}{*}{ Space } & Sluices & 39 & $5(5.5)$ & $3(1.0)$ & $11(2.7)$ & $3(1.2)$ & $3(5.5)$ & $1(1.3)$ \\
\hline & Bay & 25 & $4(4.4)$ & $7(2.2)$ & $4(2.2)$ & $1(0.59)$ & $1(0.69)$ & $2(0.86)$ \\
\hline & Height & 14 & $4(4.4)$ & $4(1.3)$ & $3(1.6)$ & $1(0.59)$ & $0(0)$ & $1(0.43)$ \\
\hline & Surface & 14 & $2(2.2)$ & $2(0.64)$ & $4(2.2)$ & $4(2.3)$ & $1(0.69)$ & $0(0)$ \\
\hline & Bottom & 14 & $0(0)$ & $6(1.9)$ & $0(0)$ & $8(4.7)$ & $0(0)$ & $0(0)$ \\
\hline & Estuary & 9 & $1(1.1)$ & $3(1.0)$ & $2(1.1)$ & $1(0.59)$ & $0(0)$ & $1(0.43)$ \\
\hline \multirow[t]{6}{*}{ Time } & Tide & 30 & $1(1.1)$ & $7(2.2)$ & $2(1.1)$ & $10(5.9)$ & $1(0.69)$ & $2(0.86)$ \\
\hline & Month & 25 & $1(1.1)$ & $4(1.3)$ & $0(0)$ & $0(0)$ & $1(0.69)$ & $1(0.43)$ \\
\hline & Year & 16 & $0(0)$ & $1(0.3)$ & $0(0)$ & $0(0)$ & $1(0.7)$ & $3(0.3)$ \\
\hline & Day & 16 & $5(5.5)$ & $2(0.64)$ & $5(2.7)$ & $1(0.59)$ & $0(0)$ & $2(0.86)$ \\
\hline & Week & 15 & $5(5.5)$ & $3(1.0)$ & $2(1.1)$ & $0(0)$ & $0(0)$ & $3(1.3)$ \\
\hline & Morning & 14 & $1(1.1)$ & $3(1.0)$ & $7(3.8)$ & $2(1.2)$ & $0(0)$ & $0(0)$ \\
\hline Financial & Financial aids & 20 & $0(0)$ & $0(0)$ & $4(2.2)$ & $0(0)$ & $1(0.69)$ & $3(1.3)$ \\
\hline \multirow[t]{4}{*}{ issues } & Ministry & 9 & $0(0)$ & $0(0)$ & $0(0)$ & $0(0)$ & $0(0)$ & $0(0)$ \\
\hline & Losses & 9 & $0(0)$ & $2(0.64)$ & $0(0)$ & $0(0)$ & $0(0)$ & $0(0)$ \\
\hline & Money & 2 & $0(0)$ & $0(0)$ & $0(0)$ & $0(0)$ & $0(0)$ & $0(0)$ \\
\hline & Cost reduction & 2 & $0(0)$ & $0(0)$ & $0(0)$ & $0(0)$ & $0(0)$ & $0(0)$ \\
\hline
\end{tabular}


Table 2. Water-body specific incidence proportion of cases of mussel mortality observed by the farmers ${ }^{e e}$ network in Pertuis Charentais, France, 2014

\begin{tabular}{lccc}
\hline Water body & Number of cases & $\begin{array}{c}\text { Total number of } \\
\text { production areas }\end{array}$ & $\begin{array}{c}\text { Incidence } \\
\text { proportion }(\%)\end{array}$ \\
\hline FRGC53 & 8 & 8 & 100 \\
FRGT31 & 2 & 2 & 100 \\
FRGC54 & 3 & 3 & 100 \\
FRFC01 & 1 & 2 & 50 \\
FRFC02 & 2 & 3 & 66 \\
\hline
\end{tabular}


North Water Bodies Production areas

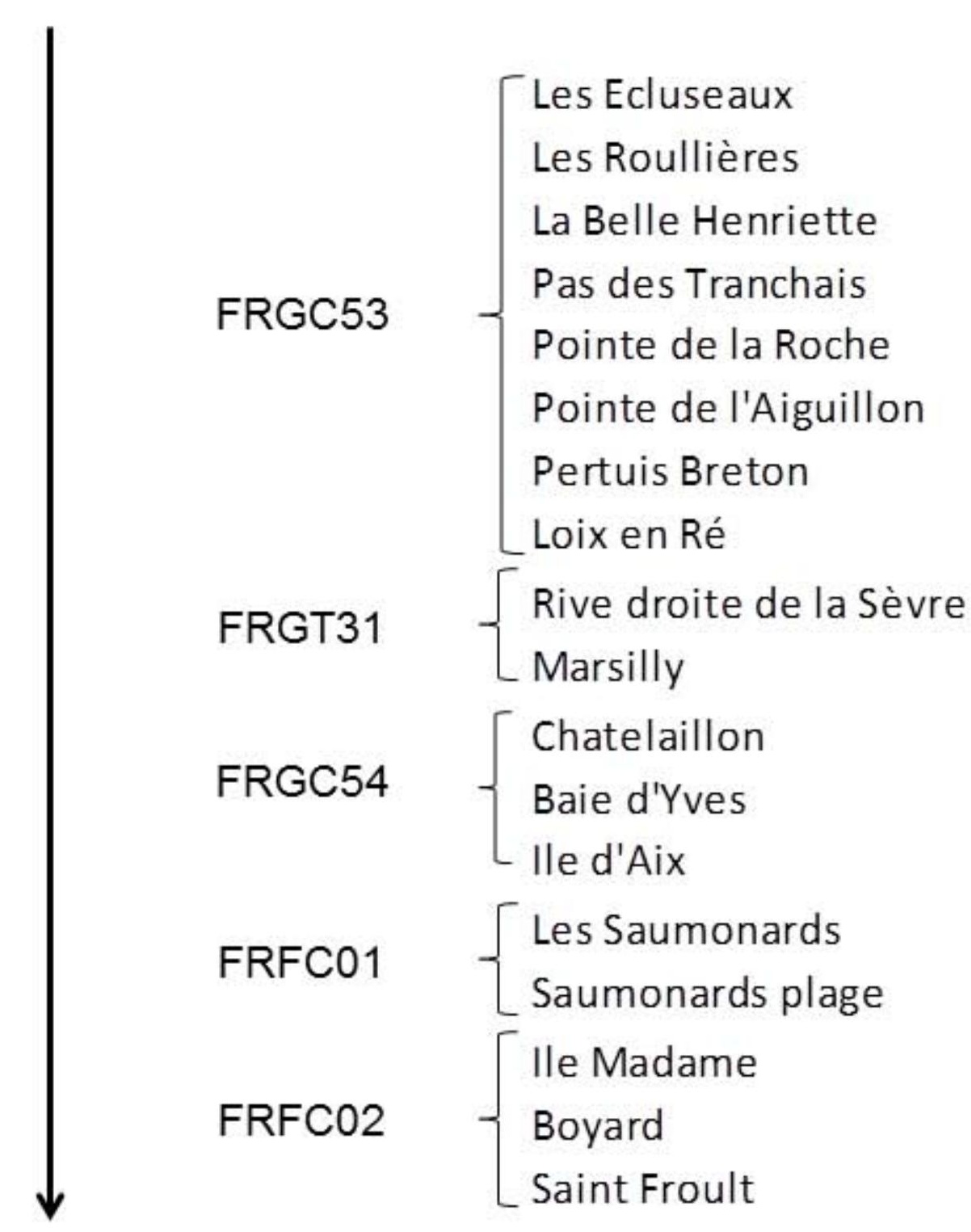

Weeks

$\begin{array}{lllllllll}9 & 10 & 11 & 12 & 13 & 14 & 15 & 16 & 17\end{array}$

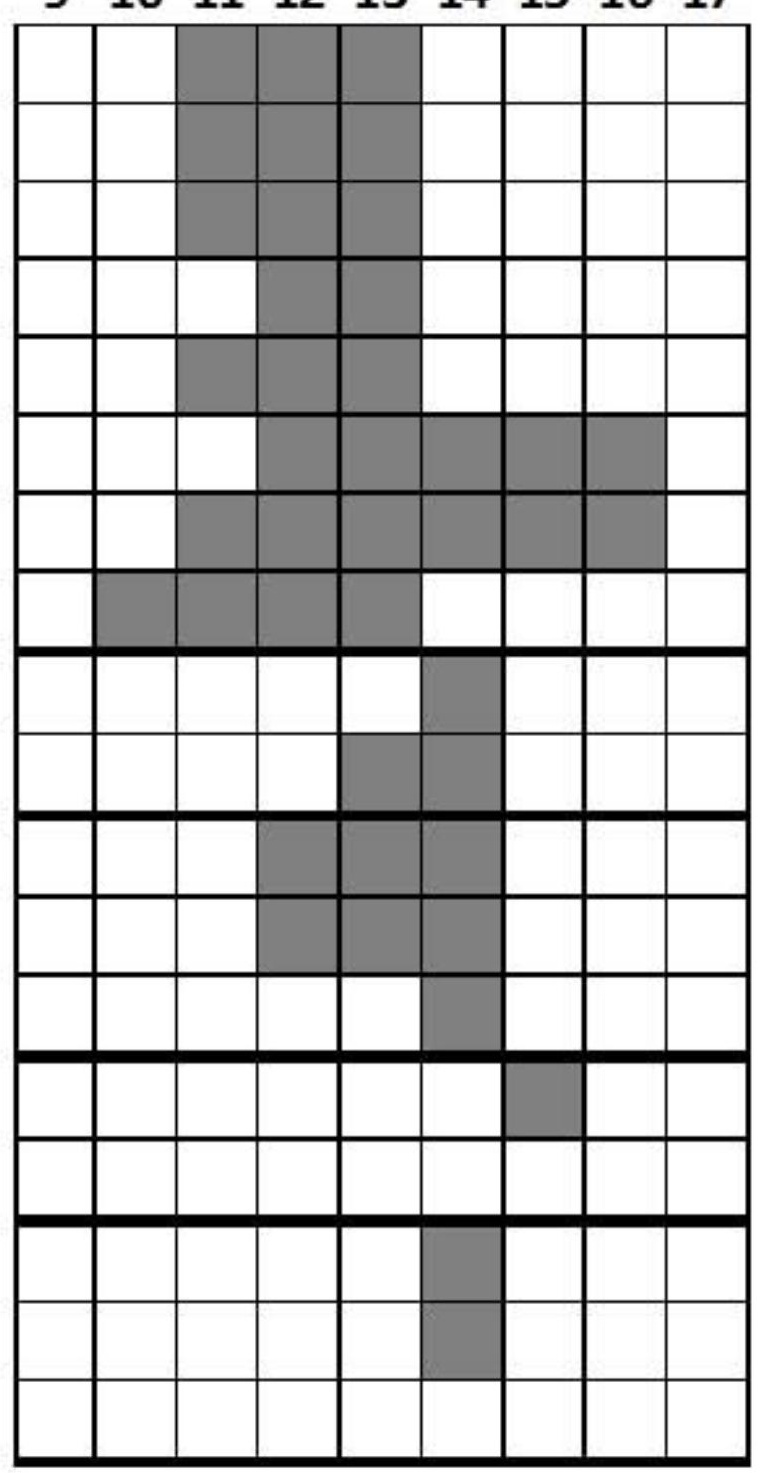




\section{Interviews}

2014-N²

induces

\section{4-N³}

2014-N5

2

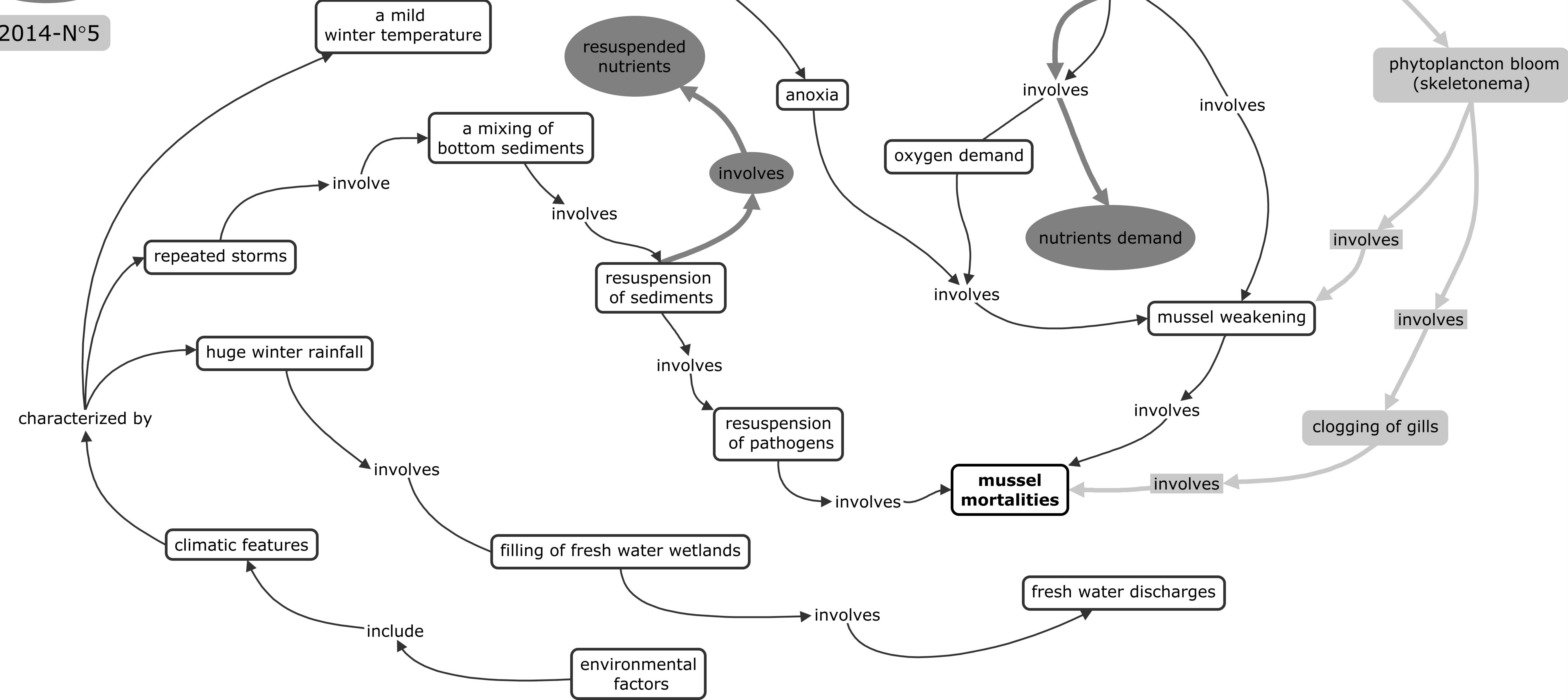


Number of cases detected by the farmers' network

12

\section{(1)}

$\therefore$

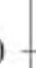

8

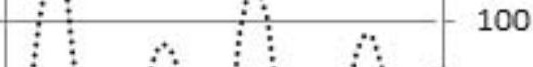

6

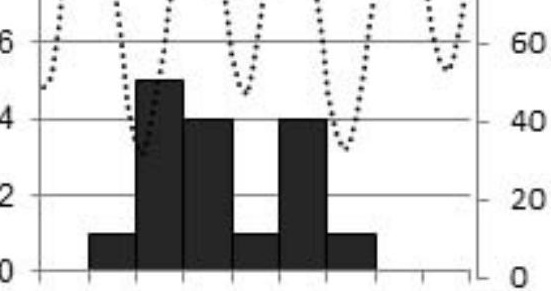

Number of notifications to 12 the DDTM

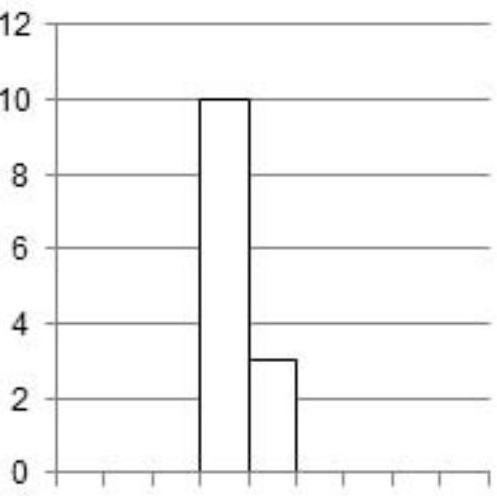

Number of notifications 12 investigated by the Repamo
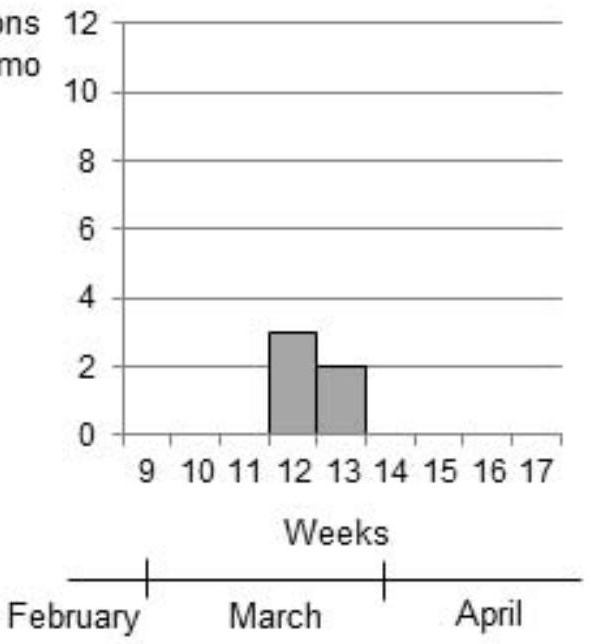


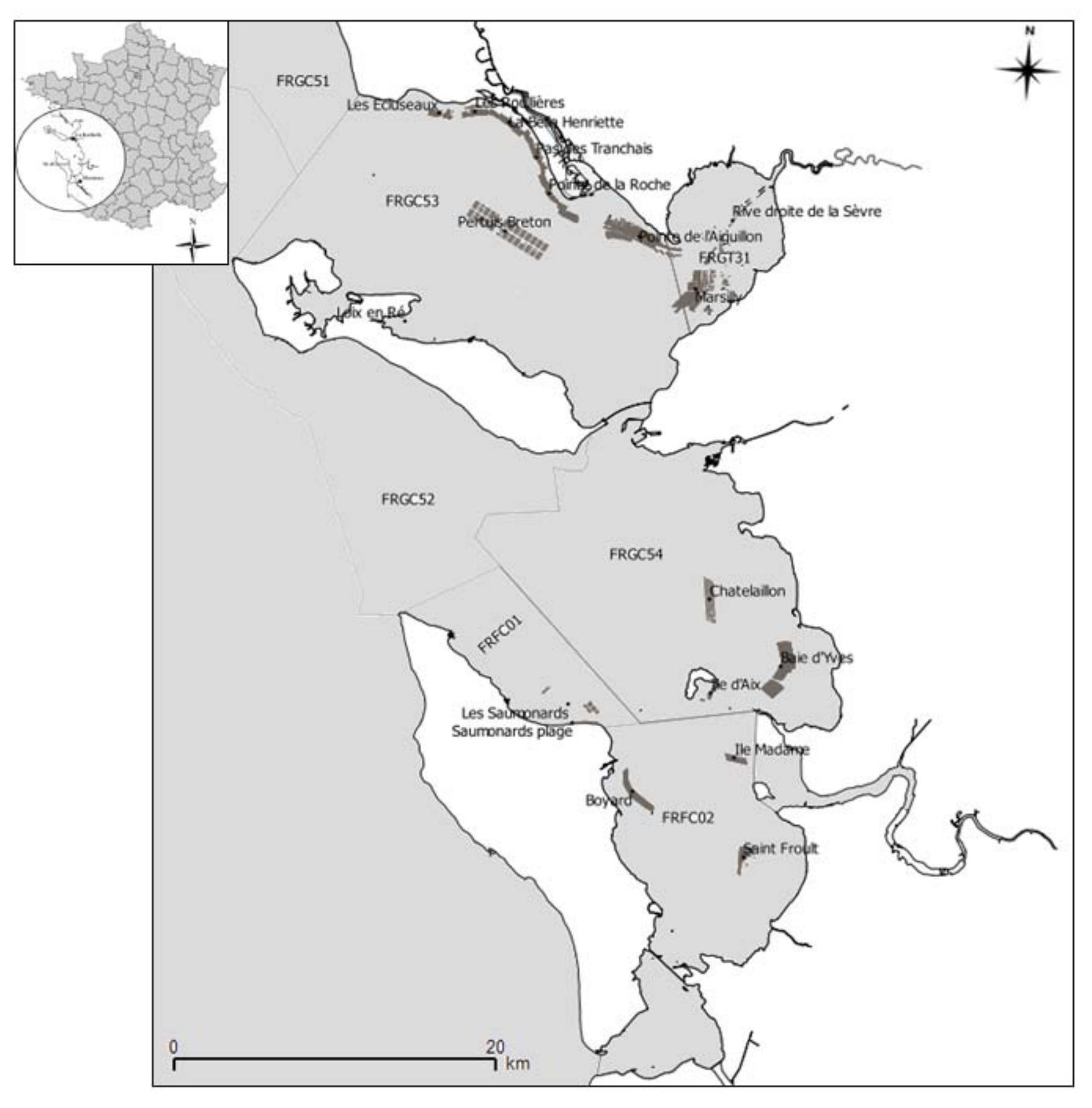

